\title{
A dual-respiration chamber system with automated calibration.
}

Citation for published version (APA):

Schoffelen, P. F. M., Westerterp, K. R., Saris, W. H. M., \& ten Hoor, F. (1997). A dual-respiration chamber system with automated calibration. Journal of Applied Physiology, 83(69), 2064-2072.

https://doi.org/10.1152/jappl.1997.83.6.2064

Document status and date:

Published: 01/01/1997

DOI:

10.1152/jappl.1997.83.6.2064

Document Version:

Publisher's PDF, also known as Version of record

\section{Please check the document version of this publication:}

- A submitted manuscript is the version of the article upon submission and before peer-review. There can be important differences between the submitted version and the official published version of record.

People interested in the research are advised to contact the author for the final version of the publication, or visit the DOI to the publisher's website.

- The final author version and the galley proof are versions of the publication after peer review.

- The final published version features the final layout of the paper including the volume, issue and page numbers.

Link to publication

\footnotetext{
General rights rights.

- You may freely distribute the URL identifying the publication in the public portal. please follow below link for the End User Agreement:

www.umlib.nl/taverne-license

Take down policy

If you believe that this document breaches copyright please contact us at:

repository@maastrichtuniversity.nl

providing details and we will investigate your claim.
}

Copyright and moral rights for the publications made accessible in the public portal are retained by the authors and/or other copyright owners and it is a condition of accessing publications that users recognise and abide by the legal requirements associated with these

- Users may download and print one copy of any publication from the public portal for the purpose of private study or research.

- You may not further distribute the material or use it for any profit-making activity or commercial gain

If the publication is distributed under the terms of Article $25 \mathrm{fa}$ of the Dutch Copyright Act, indicated by the "Taverne" license above, 


\title{
A dual-respiration chamber system with automated calibration
}

\author{
PAUL F. M. SCHOFFELEN, KLAAS R. WESTERTERP, \\ WIM H. M. SARIS, AND FOPPE TEN HOOR ${ }^{\dagger}$ \\ Department of Human Biology, Maastricht University, 6200 MD Maastricht, The Netherlands
}

\begin{abstract}
Schoffelen, Paul F. M., Klaas R. Westerterp, Wim H. M. Saris, and Foppe Ten Hoor. A dual-respiration chamber system with automated calibration. J . Appl. Physi ol . 83(6): 2064-2072, 1997.-This study characterizes respiration chambers with fully automated calibration. The system consists of two 14- $\mathrm{m}^{3}$ pull-type chambers. Care was taken to provide a friendly environment for the subjects, with the possibility of social contact during the experiment. Gas analysis was automated to correct for analyzer drift and barometric pressure variations and to provide ease of use. Methods used for checking the system's performance are described. The gas-analysis repeatability was within $0.002 \%$. Results of alcohol combustion (50-350 $\mathrm{ml} / \mathrm{min} \mathrm{CO}_{2}$ ) show an accuracy of $0.5 \pm 2.0$ (SD) \% for $\mathrm{O}_{2}$ consumption and $-0.3 \pm$ $1.6 \%$ for $\mathrm{CO}_{2}$ production for 2- to $24-\mathrm{h}$ experiments. It is concluded that response time is not the main factor with respect to the smallest practical measurement interval (duration); volume, mixing, gas-analysis accuracy, and levels of $\mathrm{O}_{2}$ consumption and $\mathrm{CO}_{2}$ production are at least equally important. The smallest practical interval was 15-25 min, as also found with most chamber systems described in the literature. We chose to standardize $0.5 \mathrm{~h}$ as the minimum measurement interval.
\end{abstract}

indirect calorimetry; energy expenditure; oxygen consumption and carbon dioxide production; measurement interval

ENERGY EXPENDITURE IN HUMANS can be determined by direct measurement of heat loss (direct calorimetry) or by calculation of heat production from $\mathrm{O}_{2}$ consumption $\left(\mathrm{VO}_{2} ; \mathrm{ml} / \mathrm{min}\right), \mathrm{CO}_{2}$ production $\left(\mathrm{VCO}_{2} ; \mathrm{ml} / \mathrm{min}\right)$, and nitrogen loss in urine. $\mathrm{VO}_{2}$ and $\mathrm{VCO}_{2}$ may be determined with a variety of methods usually involving a mouthpiece, face mask, or ventilated hood $(2,9,20)$, limiting the duration of the measurement to a few hours. F or the determination of $\mathrm{VO}_{2}$ and $\mathrm{VCO}_{2}$ during a longer time interval (up to several days), a respiration chamber may bethe method of choice (1, 3-6, 8, 11- 19). During the measurement, the subject stays in an airtight room through which a stream of fresh air is directed. Composition and volume of the inlet and outlet airstream are measured. The respiration chambers described bel ow feature a double set of gas analyzers with continuous automated calibration and automated data collection. This approach circumvents most problems due to ambient variations in gas composition and pressure and due to operator errors. Independent checks of the automated calibration procedure are performed regularly by using alcohol combustion or injection of gas with known composition. The chambers have been operational for over 10 years and provide an

† Deceased 1 October 1997. easy-to-use and labor-saving service with minimum downtime.

\section{METHODS}

\section{Subject Environment}

Two equally sized $\left(14 \mathrm{~m}^{3}\right)$ and furnished chambers were placed next to each other (Fig. 1). They give the impression of a normal room, with windows positioned in the door for contact with researchers, in the wall (outside view), and between the chambers for visual contact between subjects. Curtains ensure privacy when needed. Each chamber has a full-sized foldaway bed, a bureau with built-in sink, a folding chair, a color tel evision set, an audiocassette player, an alarm clock, a telephone, an automated intercom, and a computernetwork connection. Confined spaces were avoi ded because of the adverse effect on the air-mixing process (APPENDIX A). Both chambers are occupied simultaneously, preventing subjects from feeling isolated and stimulating normal domestic behavior.

The chambers are equipped with a deep-freeze toilet (Special Product, Mulders) for collecting feces; urine is collected separately in bottles. Three air locks provide passage for the exchange of food, collection of feces and urine, and for sampling of blood. Safety precautions include a fire alarm and extinguisher, emergency lighting, and panic buttons. The door can be opened from both sides without hindrance. The chambers are checked once a year for electrical safety (S1 standard), and the climate is constantly regulated and monitored by an automated information system. Physical activity can be performed by using a cycle ergometer (Lode) or a treadmill (Quinton). The height of the chamber also allows the use of a stepping platform. Activity of the subject is measured by an analog ultrasound system (Advisor DU160).

\section{Ventilation}

F or airtightness, each room was constructed of six prefabricated welded steel parts, bolted together with a sealing mass in between. Door and air locks have a flexible seal. The air in the surrounding laboratory is ventilated with fresh air at a rate of five times its volume per hour $\left(1,200 \mathrm{~m}^{3} / \mathrm{h}\right)$. F resh air from outside the building is drawn through the chambers by a ventilator with a capacity of $30-250 \mathrm{l} / \mathrm{min}$ at a negative pressure of 600-50 Pa, respectively (pull type). The flow is adjusted with a valve at the output. Negative pressure is adjusted to $250 \pm 125 \mathrm{~Pa}$ with a valve at the input and is measured by using a $U$-type oil gauge against barometric pressure. Flow is measured with dry bellows meters (G4, Meterfabriek Schlumberger) calibrated by mass-flow $\left(\mathrm{CO}_{2}\right.$ weight) from a gas bottle to $0.2 \%$. [This calibration method was periodically verified by sending a calibrated gas meter to the national standards laboratory (Nederlands Meet Instituut)] The flowmeters are equipped with a digital pulse output for continuous flow measurement. The air-conditioning has a capacity of $3,700 \mathrm{~W}$, which is mainly needed for dehumidification of the air during exercise. The air in the chambers is mixed with a radial ventilator, forcing the air 


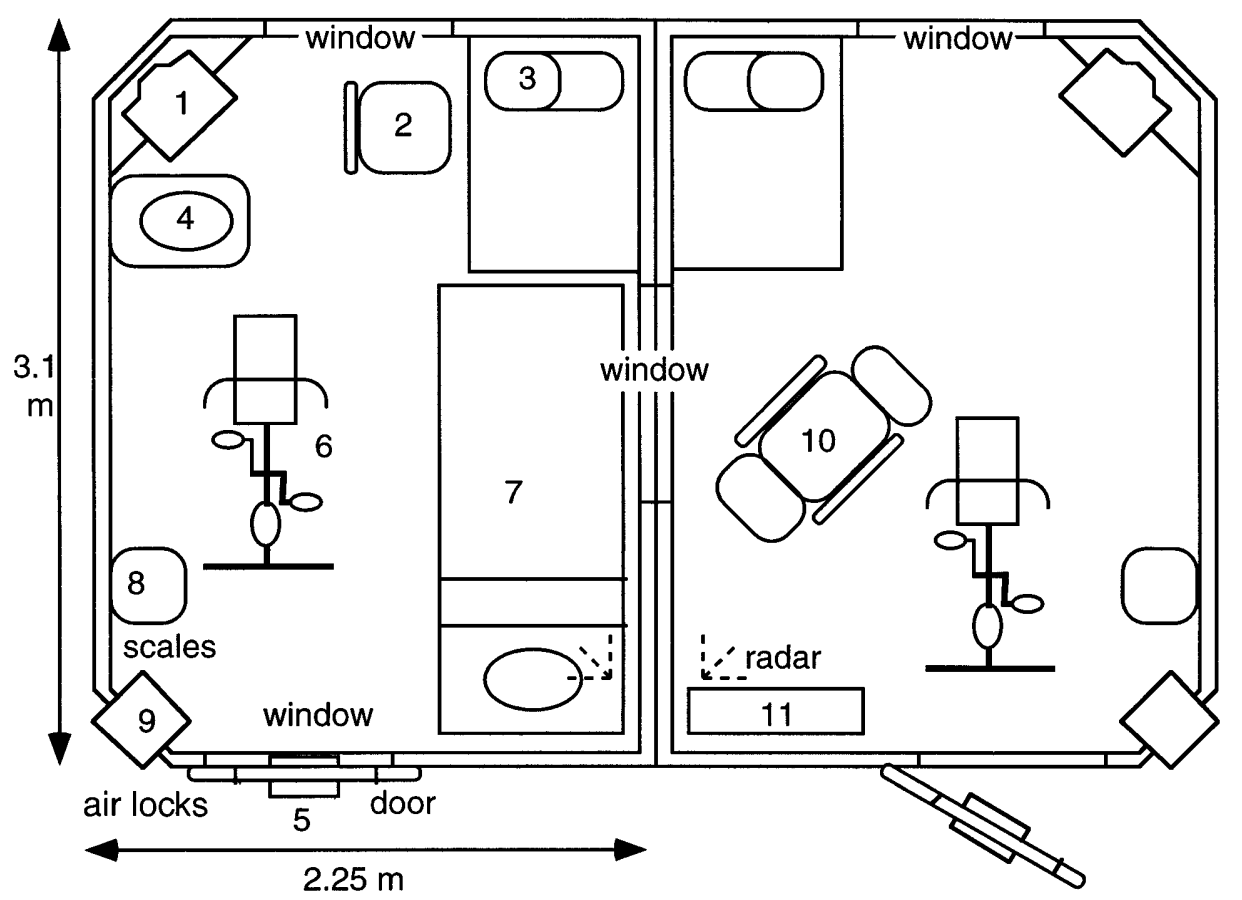

Fig. 1. Layout of dual respiration chamber. 1, Television set; 2 , chair; 3, sink with hot and cold running water; 4, deep-freeze toilet; 5 , air lock for blood samples; 6, cycle ergometer; 7, bed (fol ded down for sleeping or sitting); 8, body-weight balance; 9 , air locks, one for food, one for feces; 10, folding chair, which may be stored under bed; 11, bed (folded up for more floor space).

through a draft-reducing perforated ceiling at a controllable rate of 3,300-10,000 I/min.

The fresh-air supply is routed directly into the airconditioning for mixing and temperaturecontrol. Thetemperature variation is $\pm 0.1^{\circ} \mathrm{C}$ during rest and $\pm 0.4^{\circ} \mathrm{C}$ during exercise. The air leaves the chamber diagonally opposite the input at two levels. Volume and flow measurements are corrected to STPD by using data obtained from temperature (AD590, National Semiconductor), humidity (SA100c, Rotronic), and barometric pressure (4-801-1124, Bell \& Howell) sensors that are calibrated on a yearly basis.

\section{$\mathrm{O}_{2}$ - and $\mathrm{CO}_{2}-$ Measurement Systems}

$\mathrm{O}_{2}$ is measured by using paramagnetic $0-22 \%$ oxygen analyzers (Magnos 6G, Hartmann \& Braun; OA184A, Servomex), and $\mathrm{CO}_{2}$ is measured by using infrared $0-1 \%$ analyzers (Uras 3G, Hartmann \& Braun). To improve the reliability of the measurement, each gas sample is analyzed in duplicate, reducing the risk of losing data because of hard-to-detect failures.

Samples from the input and the output of the chamber are drawn into a sample preparation unit by using membrane pumps (model 300, Wisa). When a sample is not selected, the sample line is still flushed to reduce dead time. Pressure and humidity variations are reduced through utilization of needle valves and oil-filled overflow bubblers (constant pressure to ambient) and by using membrane dryers (ME050-24-MFL, Perma Pure). The membrane dryers have an enhanced drying capacity obtained from using an outer hull with a counterflowing dry purgegas at $50 \mathrm{KPa}$ negative pressure; this provides a steady drying capacity. The combination of fully flushed sample routes with identical delays and a membrane-drying tube resulted in a $90 \%$ response of the $\mathrm{CO}_{2}$ analyzers of $5 \mathrm{~s}$ after the switch from $\mathrm{N}_{2}$ to calibration gas. The system ensures that all samples are clean (1- $\mu \mathrm{m}$ filter) and are of equal pressure $( \pm 10 \mathrm{~Pa})$, temperature $\left( \pm 0.1^{\circ} \mathrm{C}\right)$, and humidity $\left(-15^{\circ} \mathrm{C}\right.$ dew point). The linearity error of each $\mathrm{CO}_{2}$ analyzer was reduced by constructing a linearization curve for each apparatus. The range of the linearized curve is $0-0.8 \%$; the $\mathrm{CO}_{2}$ concentration inside the chambers normally never exceeds $0.8 \%$.

The difference in gas composition (dg) between incoming and outgoing air and the ratio of $\mathrm{dg}$ to the difference in time (dt) in the chamber (derived from measurement. of the outgoing air) have to be known for the calculation of $\mathrm{VO}_{2}$ and $\mathrm{VCO}_{2}$ (APPENDIX B). Air samples are measured in sequence (10) and alternated with samples of calibration and zero gases, thus eliminating errors because of differences in analyzers or sample preparation. The measurement of each sample re quires $1 \mathrm{~min}$. During each interval of $15 \mathrm{~min}$, samples of fresh air and zero and calibration gas are measured in addition to the 12 chamber samples (Fig. 2). In this way, effects due to baseline drift, barometric pressure $(3,18)$, and temperature variation, factors that vary more slowly than in $15 \mathrm{~min}$, are minimized. Because of the full automatization, no operator action is required, eliminating this source of error.

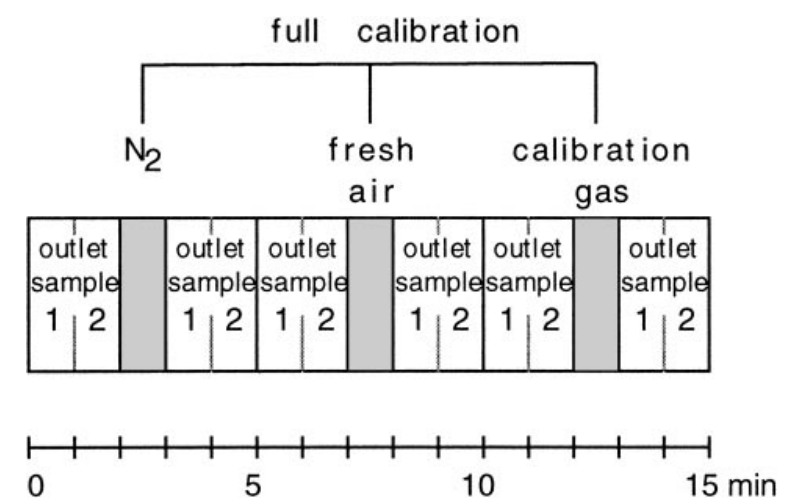

Fig. 2. Sample sequence. Inlet and outlet samples from chambers 1 and 2 are alternated with $\mathrm{N}_{2}$ (zero control), fresh air, and calibration gas, thus obtaining zero control and calibration every $15 \mathrm{~min}$. 
Calibration and fresh-air measurements account for $12 \mathrm{~min}$ every hour. The remaining $48 \mathrm{~min}$ during the hour provide time for two concentration measurements for both chambers during each of twelve 5-min intervals. $\mathrm{VO}_{2}$ and $\mathrm{VCO}_{2}$ are calculated for each 5-min interval, and the 5-min results are integrated to $0.5-\mathrm{h}$ values in the standard output file. Although it is possible to calculate 5-min values for $\mathrm{VO}_{2}$ and $\mathrm{VCO}_{2}$, the accuracy of these values will be low because the standard deviation (SD) in the measurement of the minute concentration changes is multiplied with the large volume of the chamber (13). The standard procedure is the calculation of $\mathrm{VO}_{2}$ and $\mathrm{VCO}_{2}$ over $0.5 \mathrm{~h}$ or longer time intervals.

The calibration gas contains $0.8 \% \mathrm{CO}_{2}-18 \% \mathrm{O}_{2}$-remainder $\mathrm{N}_{2}$. The $\mathrm{CO}_{2}$ concentration of this gas can be obtained with a certified accuracy of $0.008 \%$. The $\mathrm{O}_{2}$ concentration, however, has a certified accuracy of only $0.18 \%$. $\mathrm{F}$ or the $\mathrm{O}_{2}$ analysis, we therefore rely on the accuracy of the overall $\mathrm{O}_{2}$ concentration of the fresh air $(4,10,14,15)$ during a whole day, while using the $18 \% \mathrm{O}_{2}$ content of the calibration gas as a stable, but at first unknown, $\mathrm{O}_{2}$ reference. The unknown $\mathrm{O}_{2}$ concentration of the calibration gas is calculated on the basis of measurement of fresh air, $\mathrm{N}_{2}$, and calibration gas $\mathrm{O}_{2}$ concentration by using mean values over the whole experiment. The cal culated cal ibration gas $\mathrm{O}_{2}$ value is then used to determine momentary $\mathrm{O}_{2}$ concentrations during the experiment. Because the $\mathrm{O}_{2}$ concentration of the calibration gas is calculated during each experiment, monitoring the obtained calibration gas values over a 3-mo interval (lifespan of a single calibration gas bottle) provides data on the accuracy of the $\mathrm{O}_{2}$ measurement, including any drift in fresh-air $\mathrm{O}_{2}$ concentration over the 3-mointerval.

A microcomputer (Macintosh, Apple) is used to monitor the parameters for determining $\mathrm{VO}_{2}$ and $\mathrm{V}_{\mathrm{CO}_{2}}$. E ach analyzer and sensor has its own analog-to-digital converter (ADC; voltageto-frequency, VFC62, Burr-Brown) and is optically isolated from the microcomputer, enabling optimal conversion of electrical signals by reducing electrical noise from long cabling and earth loops. Calibration of sensors is done in the software; the analog range of the converters was individually chosen to handle any long-term drift. Parameters used in the calculation of $\mathrm{VO}_{2}$ and $\mathrm{V}_{\mathrm{CO}_{2}}$ are temperature, humidity, flow, barometric pressure, and a digital reading of $\mathrm{O}_{2}$ and $\mathrm{CO}_{2}$ concentrations in sample and calibration gases.

On-line calculation enables continuous monitoring of the progress of the experiment. Final calculation is done after the experiment is completed, allowing the use of all data for calculation of calibration constants (12), specifically the $\mathrm{O}_{2}$ concentration in the calibration gas bottle. The equations used in the calculation of gas exchange are based on the assumption of $\mathrm{N}_{2}$ conservation ["haldane" correction $(3,5,7$, 10-12, 15-17)] with incorporation of differentiated changes in the chamber volume for the $\mathrm{N}_{2}$ equation $\left[\mathrm{dF} \mathrm{N}_{2} / \mathrm{dt}\right.$; determined at the outlet $(3,7,12,17)]$. Water vapor is taken into account $(3,10)$ by first calculating all flow and volumes [including differentiated changes in the chamber volume $\left.\left(\mathrm{dH}_{2} \mathrm{O} / \mathrm{dt}\right)\right]$ to STPD. E nergy expenditure is calculated from $\mathrm{VO}_{2}$ and $\mathrm{VCO}_{2}$ with the Weir formula (21).

To achieve flexibility, the software for the system is modular; data acquisition is based on a graphical engineering program (Labview, National I nstruments), and calculation is performed with a spreadsheet macro program (Excel, Microsoft). Additional parameters can be incorporated by using the flexibility of the software and the network capability of the computer (network-connected ADCs and serial ports). The audio capability of the computer (speech) was used to synchronize the subject's behavior to a protocol by providing an audio signal to the subject when it was time for a certain activity.

\section{Validation}

Each month, an independent check of the whole system is obtained by combusting alcohol inside the chamber or, in some instances, by injecting gas with a known composition into the chamber. The alcohol (99.8\% methanol pro analyse; Merck) is combusted by using a gas burner (Fig. 3A). The burner is placed on a calibrated balance connected to a computer to measure the rate of combustion during the experiment. When alcohol is combusted, $\mathrm{O}_{2}$ is consumed and $\mathrm{CO}_{2}$ is produced, mimicking normal measurement. With the use of gas injection with $\mathrm{CO}_{2}, \mathrm{~N}_{2}$, or a combination of both (Fig. 3B; Refs. 4, 11-14, 17, 18), the accuracy of $\mathrm{CO}_{2}$ and $\mathrm{O}_{2}$ measurement can be checked.

Calculating produced $\mathrm{CO}_{2}$ from weight should take into account that at barometric pressure the $\mathrm{CO}_{2}$ compressibility (3a) accounts for a $-0.6 \%$ deviation between molar and volume fraction, valid for both alcohol combustion and $\mathrm{CO}_{2}$ injection. In this context, it should be pointed out that calibration gas certificates can therefore be obtained on the basis of molar or volume fraction. In our setting, all calculations were done by using volume (fractions) at STPD.

The duration of validation experiments is 24 or $2 \mathrm{~h}$; both time intervals are relevant to actual experiments.

\section{RESULTS}

During operation of the system for $10 \mathrm{yr}$, only 2 of $>2,000$ subjects felt isolated and finished the experiment prematurely. No safety hazards have occurred.

\section{Ventilation}

The perforated ceiling reduced the noise at ear level to $45 \mathrm{dbA}$ at the lowest recirculation flow of 3,300 I/min. At the highest recirculation of $10,000 \mathrm{I} / \mathrm{min}$, the noise increased to $54 \mathrm{dbA}$. At the lowest recirculation flow of $3,300 \mathrm{l} / \mathrm{min}$ and a flow through the chamber of $50 \mathrm{l} / \mathrm{min}$,

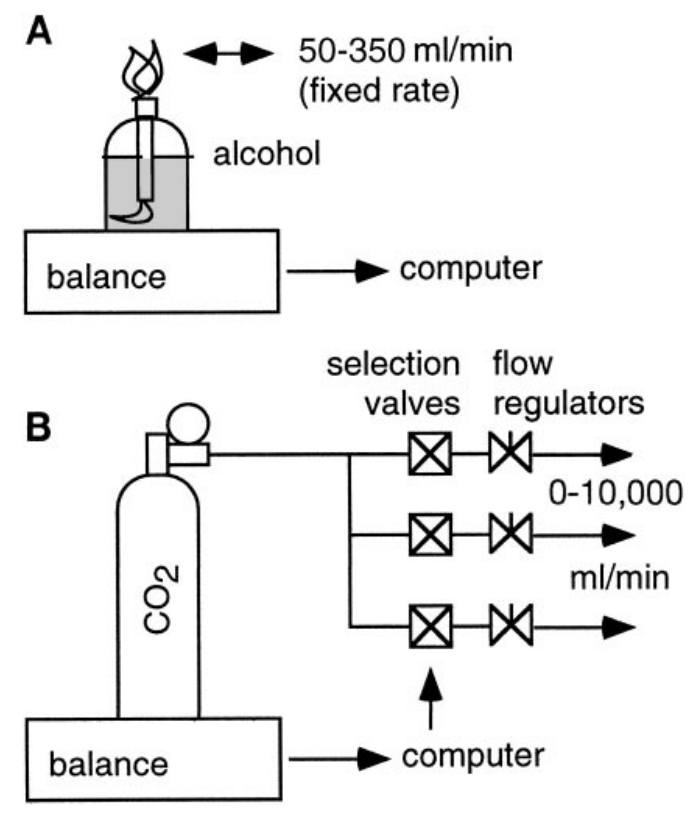

Fig. 3. Chambers are checked by combustion of alcohol (A) or infusion of $\mathrm{CO}_{2}$ (B). Amount of combusted alcohol or injected gas is calculated from weight change of containers; connecting balance to a computer allows continuous measurement of rate of combustion or infusion. Computer can change this rate during experiment if computer-controlled valves (B) are used. 
$99 \%$ of a 5 -min continuous injection was measured within $15 \mathrm{~min}$, and $63 \%$ was measured in $5 \mathrm{~min}$.

\section{$\mathrm{O}_{2}$ - and $\mathrm{CO}_{2}$-Measurement System}

Key elements in the gas-analysis system are the sampling system and the reproducibility of the gas analyzers. The time needed to flush the sampling system after a change of sample was measured to be $\leq 5 \mathrm{~s}$, leaving $55 \mathrm{~s}$ for stabilization lat least 10-fold; analyzer response time [reponse time to $90 \%\left(t_{90}\right) \leq 3.5$ s] and measurement. The drying capacity of the sampling system, particularly important for measuring $\mathrm{O}_{2}$, showed a steady sample dew point lower than $-15^{\circ} \mathrm{C}$. To check the reproducibility of the $\mathrm{O}_{2}$ analyzers, the difference between two analyzers was measured over the $0-18 \% \mathrm{O}_{2}$ concentration range (Fig. 4) when identical gas samples were measured. The signal-to-noise levels had an SD $<0.002 \%(n=75)$, illustrating the reproducibility of the $\mathrm{O}_{2}$ gas analysis.

Validation

Alcohol-combustion experiments over the present year $(n=44)$ resulted in differences between "alcohol combustion" values and "chamber system" values of $-0.3 \pm 1.6 \%$ for $\mathrm{CO}_{2}, 0.5 \pm 2.0 \%$ for $\mathrm{O}_{2}$ (Fig. 5) and a respiratory quotient of $0.663 \pm 0.012$. No difference was found between 2 - and $24-h$ tests. The results of calibration experiments using $\mathrm{CO}_{2}$ injection over the past years were comparable with those found for alcohol combustion $(-0.6 \pm 2.3 \%, n=20)$.

The system compares the stable $\mathrm{O}_{2}$ concentration of the calibration gas with the mean 24-h fresh-air $\mathrm{O}_{2}$ concentration; the variation in these $24-\mathrm{h} \mathrm{O}_{2}$ concentration measurements can be determined. Maximum difference in 24-h measurements over the 3-mo lifespan of a calibration gas bottle was found to vary from $0.003 \pm$ 0.002 to $0.006 \pm 0.004 \% \mathrm{O}_{2}$. This variation can be attributed to both variation in fresh air $\% \mathrm{O}_{2}$ and variation in the measurement system; these factors

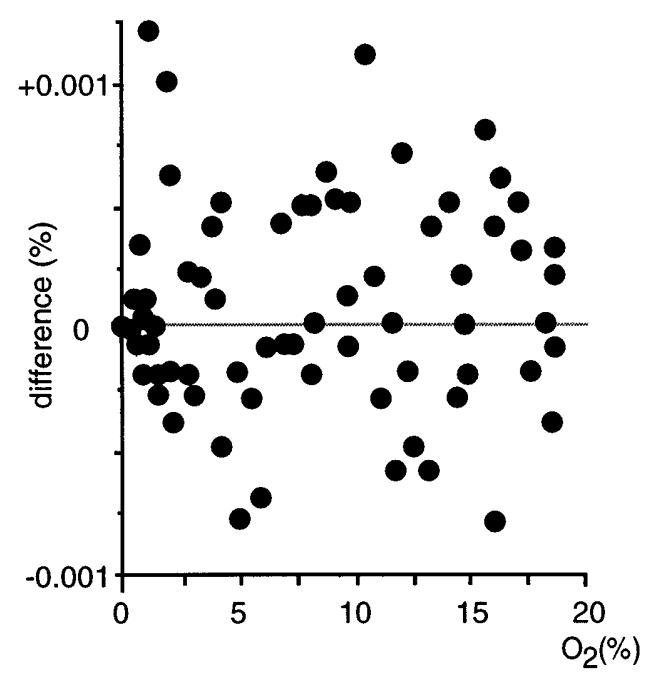

Fig. 4. Difference between 2 analyzer cells (y-axis, \%) when identical samples are measured as a function of $\mathrm{O}_{2}$ concentration in measured gas (x-axis, \%).

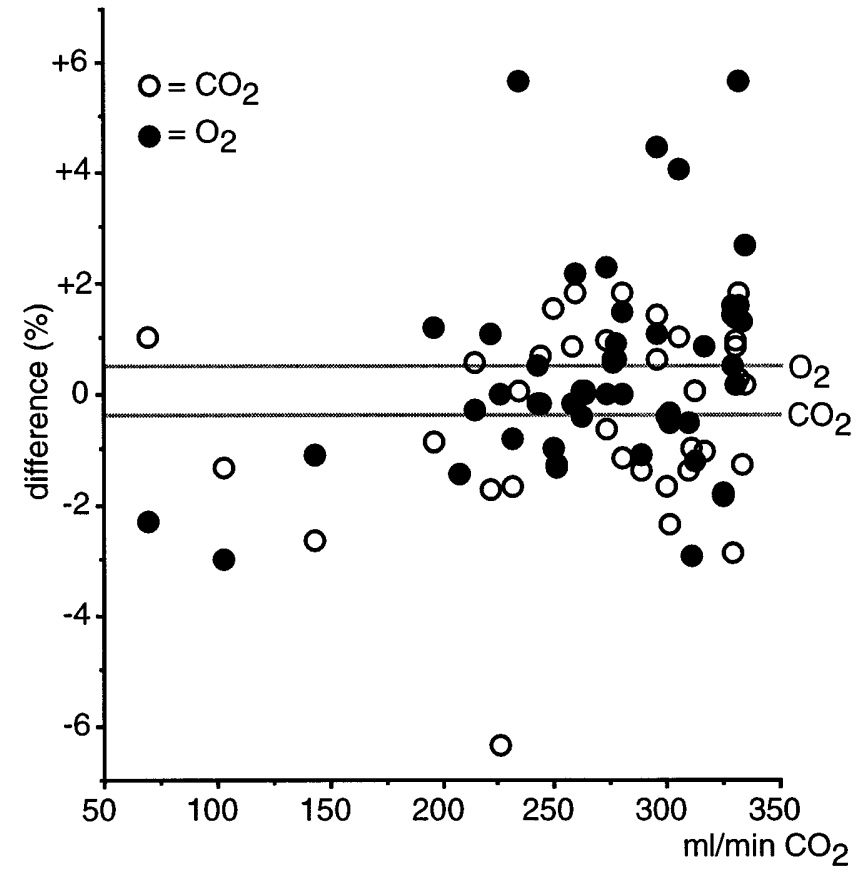

Fig. 5. Results of alcohol-combustion experiments. Difference be tween amount calculated from alcohol combustion and amount measured by system ( $y$-axis, \%) as a function of $\mathrm{CO}_{2}$ production by alcohol combustion (x-axis, $\mathrm{ml} / \mathrm{min}$ ) is shown.

cannot be separated. Because these variations are also both present in normal experiments, the maximum difference found is an indication of the performanceand stability of the system with respect to calibration based on fresh air $\mathrm{OO}_{2}$. If calculated $\mathrm{O}_{2}$ concentration in the calibration gas was compared by using data of two $\mathrm{O}_{2}$ analyzers, the maximum difference and SD increased by $50 \%$, showing the advantage of measuring input and output concentrations sequentially $(10,14)$ with one analyzer compared with measurement of input and output concentrations with separate analyzers.

Registration of energy expenditure and physical activity of a subject is shown in Fig. 6. Energy expenditure data are given for $0.5-\mathrm{h}$ intervals. Physical activity was synchronized with these 0.5 -h intervals by using computer audio.

\section{DISCUSSION}

Subject Environment

After the creation of a friendly environment, only noise and draft due to air conditioning remain as the major factors compromising comfort. The rate of recirculation flow is therefore limited (12) and, because of its cooling effect, the room temperature is normally set a few degrees higher $\left(\leq 3^{\circ} \mathrm{C}\right)$ than at home.

\section{Ventilation}

The recirculation flow range of ventilating the 14- $\mathrm{m}^{3}$ volume at a rate of 15-42 times per hour calculates to a mixing time constant (12) of 1.4-4.2 min, which is comparable to those calculated from the literature $(4-6,12,14-16)$, ranging from 0.4 to $4 \mathrm{~min}$. The result 
Fig. 6. Energy expenditure (EE) and physical activity of a subject (male, aged $32 \mathrm{yr}$, body weight $68 \mathrm{~kg}$ ) as measured over 0.5 -h intervals.
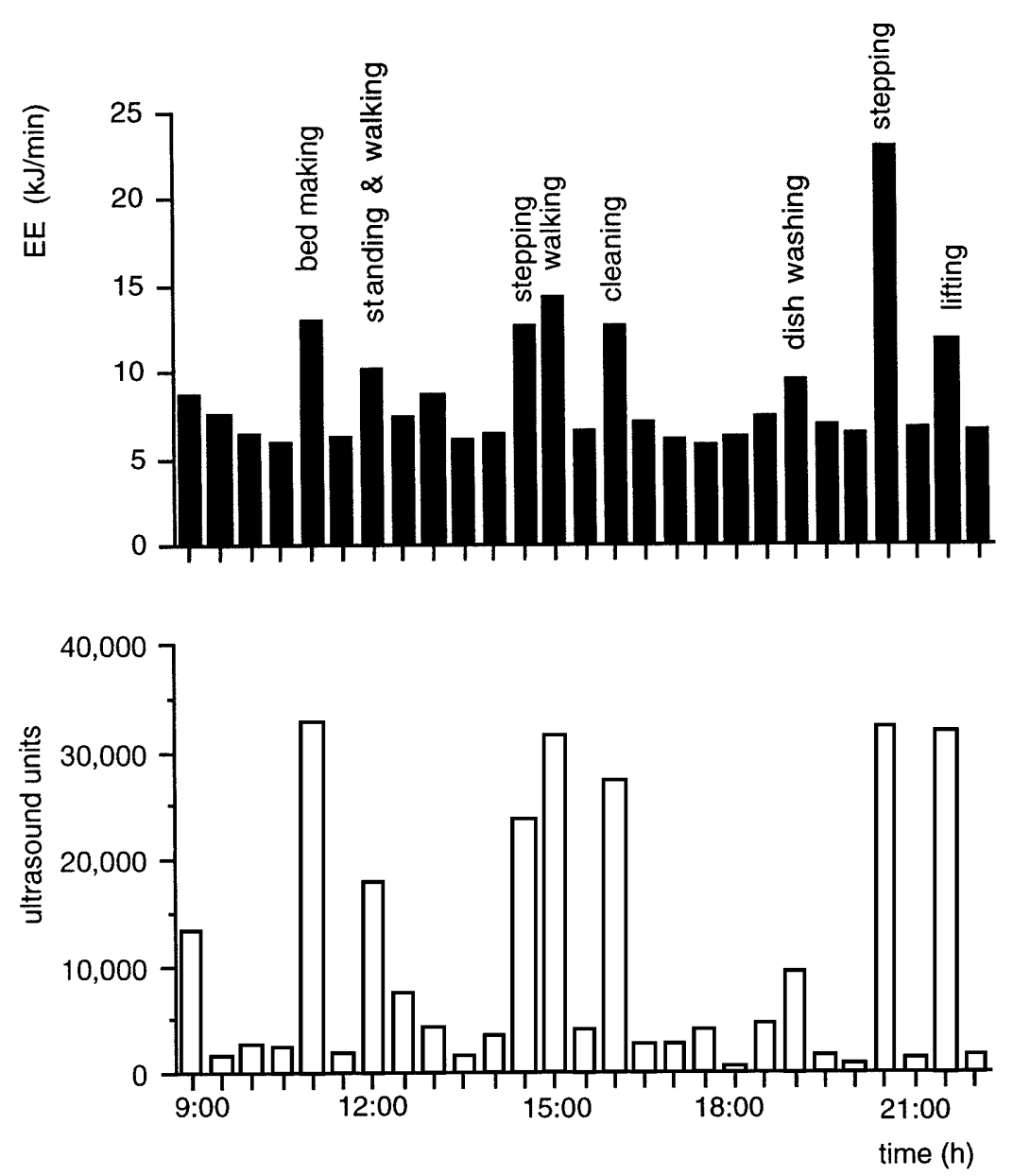

of observing $99 \%$ of a 5-min continuous injection within $15 \mathrm{~min}$ is slightly better than expected from the calculated 4.2-min time constant at the lowest recirculation rate. Extending the recirculation flow range will either compromise the mixing time constant ( $\geq 4 \mathrm{~min}$ ) or the comfort of the subject. The negative pressure [pull type $(5,8,13,15)$ ] ensures that airflow through leaks will only be from outside to inside the chamber. If the room around the chamber is well ventilated, this will have a negligible effect on the measurements. In some settings, factors like environment (4) or control of inlet air $(11,12)$ can necessitate the use of a positive pressure system. Such a system [push type $(4,6,11,12,14$, $16-18)$ ] requires better sealing $(12,16)$ because it cannot be guaranteed that leaked air was already completely mixed and sampled.

Wherever possible, care was taken to avoid confined spaces, which would act as buffer volumes. A confined space behaves as a volume in which gas concentrations will slowly follow the concentration in the chamber. If a subject's expired air is directed to a confined space, the mixing time will increase. For this reason, no closed cabinets were provided inside the chambers and the cabinets around equipment like the deep-freeze toilets and tel evision sets were perforated.

\section{$\mathrm{O}_{2}$ - and $\mathrm{CO}_{2}-\mathrm{M}$ easurement System}

The automated system operates continuously, and thus the system is calibrated 96 times/24 h. The SD < $0.004 \%$ in the daily calculated $\mathrm{O}_{2}$ concentration of the calibration gas over 3 mo shows the capability of the system for handling environmental variation and drift. As far as we know from the literature, this frequent automated calibration is a unique feature of the system, making it easy to use; to start an experiment, one has only to close the door of the chamber. Multiplexing samples in time on one analyzer $(10,14)$, rather than using multiple analyzers, combined with interleaved (frequent) calibration, eliminates the need for temperature and pressure correction $(3,18)$ when momentary concentration values are calculated, because the time of calibration is almost identical to the measurement time $(\leq 15 \mathrm{~min})$.

\section{Validation}

The results of the alcohol-combustion tests were $-0.3 \pm 1.6 \%$ for $\mathrm{CO}_{2}$. One factor determining the accuracy is the $\mathrm{CO}_{2}$ concentration in the calibration gas, which in our case was determined to be $0.8 \pm$ $0.008 \%$. Elimination of this possible source of deviation 
would require a certificate with an accuracy of $0.8 \pm$ $0.0008 \%$ for the $\mathrm{CO}_{2}$ component and possibly further improved linearization of the analyzers. However, neither was available.

The $0.5 \pm 2.0 \%$ result for $\mathrm{O}_{2}$ is only achievable with analyzers that perform well within the factory specification and requires meticulous sample preparation and stable laboratory conditions. The reason for this is the $\sim 20 \% \mathrm{O}_{2}$ background in all measured air because every type of analyzer has to deal with a $20 \%$ background in relation to a $1 \%$ measurement span, requiring a $21 \%$ physical measurement range for a $1 \%$ differential physiological range. This is easily understood for massspectrometer (17) and paramagnetic optical analyzers that measure one gas stream; they can only be differential in time $(10,14)$. However, it is also valid for dual-gas stream differential analyzers because these use dual compartments (magnetic wind principle) for comparison, and in each of these compartments the $20 \%$ background again largely determines the signal-tonoise ratio. Because the result of subtracting the background in differential analyzers is instantaneous, it is often erroneously assumed that the $20 \%$ background is eliminated from the physical measurement.

Alcohol combustion is normally used.for checking experiments because it tests $\mathrm{VO}_{2}$ and $\mathrm{VCO}_{2}$ simultaneously and experiments are easy to perform. However, for troubleshooting, $\mathrm{CO}_{2}$ and $\mathrm{N}_{2}$ infusion is the method of choice because it is independent of a chemical reaction. The slightly larger error margin in the $\mathrm{CO}_{2-}$ infusion experiments (over several years) compared with the regular alcohol-combustion experiments (over $1 \mathrm{yr}$ ) is attributable to the fact that gas infusion was mostly used for troubleshooting when a problem was detected.

\section{Response Timeand Measurement I nterval}

In the literature, two types of system responses are given. One is actually the time constant (therefore, not referred to as response time in this study) of the mixing process $(8,12,15)$, and the other is the (90-99\%) response time of the complete system to a change in energy expenditure $(4,6,11,12,14)$. The response time incorporates the mixing time constant (because all air should first be well mixed) and will therefore be larger than the mixing time constant. The response time is only important, in part, when measurement protocol is decided on, i.e., rate of change of energy expenditure to be measured. The volume of the chamber, the rate of gas flow through the chamber, and the accuracy of the gas measurement determine the interval (duration) needed to reach $95 \%$ of accuracy. N ormally, this interval is at least $1 \mathrm{~h}$, as can be seen from calibration experiments (Table 1, Refs. 4, 6, 8, 11, 12, 15-17, 19), even if the response time is much smaller $(4,6,11,12$, $14,15,17)$. Furthermore, it is not proven that subjects will behave in the same way as the testing methods, specifically with respect to the mixing and leaking (push-type chamber) of the subject's expired air, because the subject can direct his breath and move in any direction inside the chamber in an unpredictable manner. This may be the reason that virtually all publications refer to a minimum measurement interval (duration) of 15-30 min, as illustrated in Table 1.

Today's line of research is often a combination of long-term observations with short-term changes in energy expenditure. If, for example, the $\mathrm{O}_{2}$ concentration SD of $0.002 \%$, which is the SD we found for our calibration gas $\mathrm{O}_{2}$ concentration check over $3 \mathrm{mo}$, is applied to a subject with a $\mathrm{Vo}_{2}$ of $350 \mathrm{ml} / \mathrm{min}$ for a $0.5-\mathrm{h}$ interval, the resulting SD in $\mathrm{VO}_{2}$ will be $\sim 3 \%$. In reality, the shorter intervals have a slightly lower SD because the short-term stability of the $\mathrm{O}_{2}$ measurement is better than $0.002 \%$. In addition, the change in concentration of the chamber volume is smaller, which decreases eventual errors due to nonlinearity of $\mathrm{CO}_{2}$ analyzers.

Table 1. Overview of achieved accuracy of chambers in theliterature in relation to test duration

\begin{tabular}{|c|c|c|c|c|c|c|c|c|}
\hline & $\Delta \mathrm{O}_{2}, \%$ & $\Delta \mathrm{CO}_{2}, \%$ & $\mathrm{n}$ & $\begin{array}{c}\text { Tested } \\
\text { Duration, } \mathrm{h}\end{array}$ & $\begin{array}{l}\text { Suggested } \\
\text { Minimum } \\
\text { Duration, min }\end{array}$ & $\begin{array}{l}\text { Size, } \\
\mathrm{m}^{3}\end{array}$ & $\begin{array}{c}\text { Reference } \\
\text { No. }\end{array}$ & Checking Method \\
\hline Summary & $\begin{array}{c}-1 \pm 2.2(\mathrm{CV})^{*} \\
0.06 \pm 1.21 \\
+0.44 \pm 0.34 \\
-0.22 \pm 1.51 \\
-0.53 \pm 0.66 \\
2.3-5.8 \\
\pm 1.2 \\
-2.8 \pm 2.8 * \\
1.5 \pm 1.4(\mathrm{CV}) \\
0.3 \pm 1.54 \\
\pm 0.43 \\
-0.5 \pm 2.1 \\
0.5 \pm 2.0 \\
+0.13 \pm 1.26\end{array}$ & $\begin{array}{c}0 \pm 2.1(\mathrm{CV})^{*} \\
-0.49 \pm 1.12 \\
-0.36 \pm 0.5 \\
0.21 \pm 0.68 \\
-0.05 \pm 1.36 \\
1.9-4.9 \\
\pm 0.5 \\
-2.1 \pm 2.8 * \\
1.5 \pm 1.4(\mathrm{CV}) \\
0.4 \pm 1.34 \\
0.4 \pm 0.85 \\
0.2 \pm 2.3 \\
-0.3 \pm 1.6 \\
-0.6 \pm 2.3 \\
+0.09 \pm 0.95\end{array}$ & $\begin{array}{r}5 \\
5 \\
14 \\
14 \\
9 \\
2 \\
\\
18 \\
9 \\
30 \\
10\end{array}$ & $\begin{array}{c}3-24 \\
4-6 \\
1 \\
24 \\
24 \\
0.5 \\
\\
3-6 \\
18-22 \\
>2-24 \\
>2-24 \\
\\
24 \\
2-24 \\
2-24\end{array}$ & $\begin{array}{c}60 \\
20 \\
15-30 \\
30\end{array}$ & $\begin{array}{l}27 \\
30 \\
31 \\
34 \\
19 \\
\\
30 \\
19 \\
20 \\
20 \\
20 \\
15 \\
16 \\
14 \\
14\end{array}$ & $\begin{array}{c}4 \\
6 \\
8 \\
12 \\
12 \\
12 \\
13 \\
15 \\
16 \\
17 \\
17 \\
18 \\
19 \\
\text { Present study } \\
\text { Present study }\end{array}$ & $\begin{array}{l}\text { Butane, } \mathrm{N}_{2}+\mathrm{CO}_{2} \text { inf } \\
\text { Butane } \\
\text { Butane } \\
\mathrm{N}_{2}, \mathrm{CO}_{2} \text { inf } \\
\mathrm{N}_{2}, \mathrm{CO}_{2} \text { inf } \\
\mathrm{N}_{2}, \mathrm{CO}_{2} \text { inf } \\
\mathrm{N}_{2}, \mathrm{CO}_{2} \text { inf } \\
\text { Propane } \\
\text { Alcohol } \\
\text { Alcohol } \\
\mathrm{CO}_{2} \text { inf } \\
\mathrm{N}_{2} \text { inf } \\
\text { Propane } \\
\text { Alcohol } \\
\mathrm{CO}_{2} \text { inf }\end{array}$ \\
\hline
\end{tabular}

Summary mean \pm SD is average deviation from $0 . \Delta$, Change; $\mathrm{n}$, No. of experiments; CV, coefficient of variation; inf, infusion. $*$ Values calculated from literature. 
Although the results of "ideal" injection experiments (good mixing, predictable injection flow) show that shorter interval measurements are feasible, we chose the standard of 0.5-h results as the smallest practical time interval with subjects. The smallest experiment duration allowed (limited in software) is $2 \mathrm{~h}$, to provide at least eight automatic calibrations for the off-line calculation, although a minimum of $12 \mathrm{~h}$ is preferred (for instance, one night). The 2-h interval is al so used in our standard checking experiments because it illustrates the accuracy for measuring sleeping metabolic rate, which is done over a 2- to 3-h interval (mostly over $3 \mathrm{~h}$ ). Whenever possible, the experiment duration with subjects was chosen to be at least $24 \mathrm{~h}$.

\section{Conclusions}

The automated system with its intermittent calibration showed stable performance and can effectively be used on a 24-h/day, 7-day/wk basis. The system has a low risk of operating errors. Variations in ambient temperature and pressure have little effect because of the intermittent-calibration method.

The accuracy of the respiration chambers is dependent on the measurement interval (duration) and the level of $\mathrm{VO}_{2}$ and $\mathrm{VCO}_{2}$ to be measured. In our setting, the accuracy, described as a mean error \pm SD, is $2.1 \pm 7.4$ and $1.3 \pm 3.7 \mathrm{ml} / \mathrm{min}$ for $\mathrm{O}_{2}$ and $\mathrm{CO}_{2}$, respectively, for intervals $\leq 2 \mathrm{~h}$. Calculated energy expenditure has an accuracy of $0.7 \pm 2.3 \%$ for an adult consuming 300 $\mathrm{ml} / \mathrm{min} \mathrm{O}_{2}$.

On the basis of our experiments, the smallest time interval needed to measure a subject was 15-25 min. When measuring plateau values (constant metabolic rate), one should wait a few minutes ( $\geq 5 \mathrm{~min}$ ) after changing the plateau to accommodate the mixing time constant. The smallest time constant possible was determined, for the most part, by the mixing properties of the chamber, but the smallest practical measure ment interval (duration $0.5 \mathrm{~h}$ ) was determined by volume and gas-analysis accuracy.

\section{APPENDIX A}

Glossary

$\begin{array}{cl}\text { A } & \text { Analyzer-output uncalibrated value } \\ \text { C } & \text { Chamber } \\ \text { cal } & \text { Calibration } \\ \text { F } & \text { Volumetric fraction of gas (STPD) } \\ \text { g } & \text { Any gas } \\ \text { i } & \text { Incoming } \\ \text { o } & \text { Outgoing } \\ \text { P } & \text { Pressure } \\ \text { r } & \text { Recirculation } \\ \text { Rh } & \text { Relative humidity } \\ \text { S } & \text { Time-derivative operator, d/dt } \\ \text { sat } & \text { Saturated with water vapor } \\ \text { T } & \text { Temperature } \\ \text { t } & \text { Time } \\ t_{90} & \text { Responsetime to } 90 \% \\ \tau & \text { Time constant } \\ \tau_{d} & \text { Delay time } \\ \text { V } & \text { Volume (stPd) } \\ \text { V } & \text { Volumetric flow rate (sTPD) } \\ \text { w } & \text { Water vapor }\end{array}$

\section{Mixing Process}

Response time is understood, in general, to be the time needed for the outlet of a process to reach at least $90 \%$ of final value after a step change at the inlet. Percentages used to define the response time vary: $90 \%\left(t_{90}\right), 95 \%\left(t_{95}\right)$, and $99 \%$ $\left(t_{9 g}\right)$ are often used. A response time may be the result of complex higher-order terms. In contrast, the time constant $(\tau)$ associated with a first-order process of type $\mathrm{Y}(\mathrm{t})=$ $X \cdot\left[1-\mathrm{e}^{(-\mathrm{t} / \tau)}\right]$ or, better, in process notation $\mathrm{H}=1 /(\tau \mathrm{S}+1)$, is well defined; e.g., it takes $3 \tau$ to reach $95 \%$ and $10 \tau$ to reach 99.995\% (14.5-bit resolution) of final value.

The first-order system $1 /\left(\tau_{c 1} s+1\right)$ normally associated with a respiration chamber is only valid for a completely mixed volume; in reality, there will always be a small initial mixing interval before a subject's air is well mixed. With the use of recent fast-response respiration chambers, the measurement interval approaches the mixing interval, raising the question
Fig. 7. Diagram of 1 st-order system $1 /\left(\tau_{c 1} s+1\right)$ normally associated with a respiration chamber augmented with higher-order terms $\left(\tau_{c 2}\right.$ and $\left.\tau_{d c}\right)$ for mixing. Recirculation flow through chamber can be thought to be sum of several ( $n$ ) partial pathways, each of which has its own delay time $\tau_{\mathrm{dn}}$ and, where confined space is present, a time constant $\tau_{\mathrm{n}}\left(\tau_{\mathrm{dc}}\right.$ and $\tau_{\mathrm{c} 2}$ are a complex composite of values $\tau_{d 1 \sim n}$ and $\left.\tau_{1 \sim n}\right)$. Subject's respiration and possibly leakage take place in some of pathways, depending on subject's position in chamber. For clarity, subject's respiration and confined volume influence have been drawn only in a single pathway. $\mathrm{VO}_{2}$ and $\mathrm{VCO}_{2}, \mathrm{O}_{2}$ uptake and $\mathrm{CO}_{2}$ production, respectively.

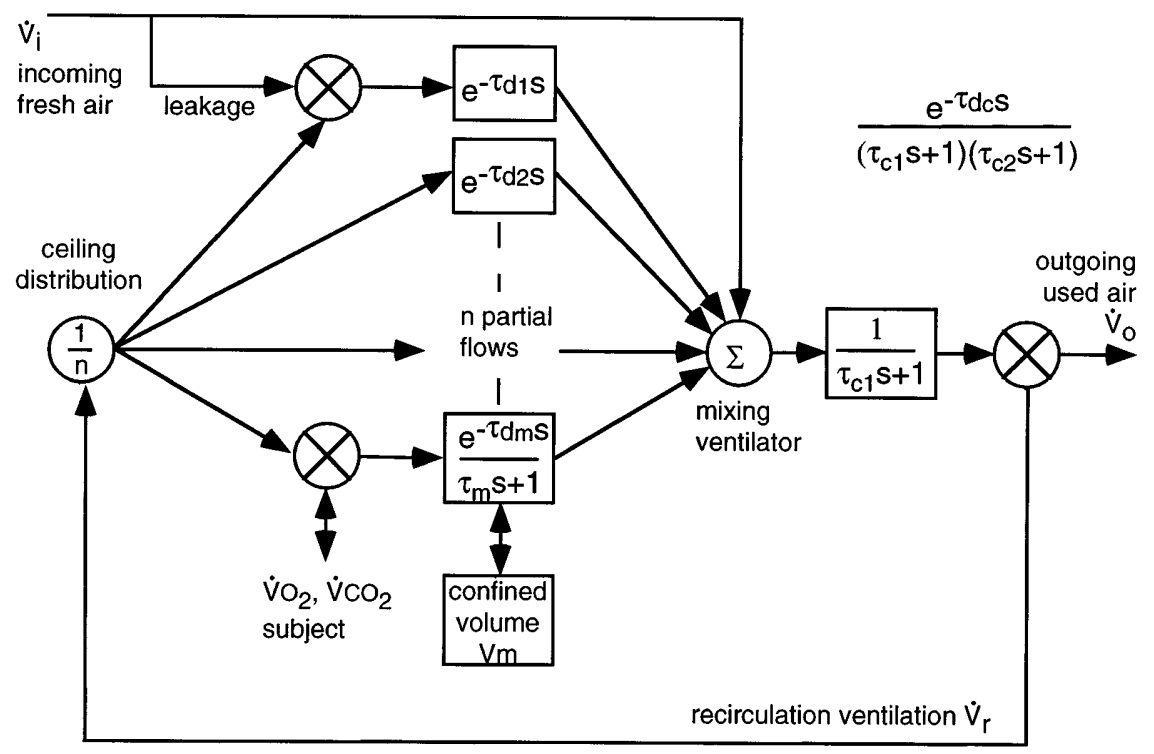


of how the mixing interval fits into the equation and which factors affect it.

The recirculation flow through the chamber (if evenly distributed) can be thought to bethe sum of several ( $n$ ) partial flows or pathways (Fig. 7), each behaving as a tube reactor. Because diffusion in a tube reactor (backward or axial mixing) is beneficial to mixing and we are interested only in the problematic dominant factors, we chose to consider each flow as an ideal tube reactor with a delay time $\left(\mathrm{e}^{-\tau_{d} \mathrm{~s}}\right)$. If a partial flow $m$ passes a confined space, an additional time constant $\left[1 /\left(\tau_{m} s+1\right)\right]$ is added for that pathway. The subject's expired air enters one or more of the pathways. Leakage will also affect one or more of the pathways, possibly where the subject respires. In a negative-pressure chamber, the direction of the leakage flow prevents loss of subject air and has the same effect as fresh air normally entering the chamber.

Determination of each parameter involved (including position and level of energy expenditure) is difficult; however, most higher-order natural proccesses can be simplified to the form $\mathrm{Ke}^{-\tau_{d} S} /\left[\left(\tau_{1} \mathrm{~S}+1\right) \cdot\left(\tau_{2} \mathrm{~S}+1\right)\right]$. This is usually also the maximum number of parameters that can be determined from measurement of standard input signals (pulse and step). When the simplified higher-order system $\mathrm{Ke}^{-\tau_{\mathrm{dc}} s} /\left[\left(\tau_{\mathrm{cl}} \mathrm{S}+1\right)\right.$. $\left(\tau_{c 2} S+1\right)$ ] with a respiration chamber $K=1$ (response at $t=\infty$ ) is used, $\tau_{d c}$ and $\tau_{c 2}$ area complex composite of values $\tau_{d 1 \sim n}$ and $\tau_{1 \sim n}$ from the $n$ partial flows, and the dominant time constant $\tau_{c 1}$ is determined by volume and flow $\left(V_{0} N_{c}\right)$. In the case of evenly distributed flow, $\tau_{\mathrm{dc}}$ will be mostly determined by volume and recirculation flow $\left(V_{d} N_{r}\right)$ and by the position of the subject in the chamber (i.e., at midpoint $0.5 \cdot V_{c} N_{r}$ ). $\tau_{c 2}$ is the result of backward and axial mixing and exchange with confined spaces. If confined spaces are avoided, $\tau_{\mathrm{c} 2}$ will be very small. Determining chamber characteristics from standard input signals (pulse and step) should take into account possible variation of $\tau_{\mathrm{dc}}$ and $\tau_{\mathrm{c} 2}$.

\section{APPENDIX B}

Calculation of $\dot{\mathrm{V}}_{2}$ and $\dot{\mathrm{V}} \mathrm{CO}_{2}$

We define two moments in time: $t_{1}$ is the start time of a single measurement, and $t_{2}$ is the end time of the measurement, i.e., in our case, $t_{2}-t_{1} \geq 5 \mathrm{~min}$, the smallest usable interval with our sample sequence. $A$ value at $t_{1}, t_{2}$, or $t_{1+2}$ (average over interval $t_{1}$ to $t_{2}$ ) represents the best value calculated from multiple samples for that point in time. Algorithms used ensure that summing values calculated over small intervals are mathematically identical to calculation over one long interval.

The frequent calibration technique allows pressure- and temperature-independent cal culations of momentary gas concentration

$$
F_{g}(t)=F_{c a l} \cdot\left[A_{g}(t)-A_{0}(t)\right] /\left[A_{\text {cal }}(t)-A_{0}(t)\right]
$$

For calculation of $\dot{\mathrm{V}}_{2}$ and $\dot{\mathrm{V}} \mathrm{CO}_{2}$, the following parameters can be derived directly

$$
\begin{gathered}
\mathrm{F}_{\mathrm{i}} \mathrm{N}_{2}(\mathrm{t})=100-\mathrm{F}_{\mathrm{i}} \mathrm{O}_{2}(\mathrm{t})-\mathrm{F}_{\mathrm{i}} \mathrm{CO}_{2}(\mathrm{t}) \\
\mathrm{F}_{\mathrm{o}} \mathrm{N}_{2}(\mathrm{t})=100-\mathrm{F}_{{ }_{\mathrm{oc}} \mathrm{O}_{2}}(\mathrm{t})-\mathrm{F}_{{ }_{\mathrm{oc}} \mathrm{CO}_{2}}(\mathrm{t})
\end{gathered}
$$

$\mathrm{P}_{\mathrm{w}}$ sat $(\mathrm{t})$ is derived from $\mathrm{T}_{\mathrm{c}}(\mathrm{t})$ by means of a lookup table.

$$
\begin{gathered}
\mathrm{P}_{\mathrm{w}}(\mathrm{t})=\mathrm{Rh}_{\mathrm{c}}(\mathrm{t}) \cdot \mathrm{P}_{\mathrm{w}} \mathrm{sat}(\mathrm{t}) / 100 \\
\dot{\mathrm{V}}_{\mathrm{o}}(\mathrm{t})=\dot{\mathrm{V}}_{\mathrm{o}} \mathrm{ATP}(\mathrm{t}) \cdot\left[\mathrm{P}_{\mathrm{o}}(\mathrm{t})-\mathrm{P}_{\mathrm{w}}(\mathrm{t})\right] /\left[1013.25 \cdot\left(1+0.00367 \cdot \mathrm{T}_{\mathrm{o}}(\mathrm{t})\right]\right. \\
\mathrm{V}_{\mathrm{c}}(\mathrm{t})=\mathrm{V}_{c} \mathrm{ATP} \cdot\left[\mathrm{P}_{\mathrm{c}}(\mathrm{t})-\mathrm{P}_{\mathrm{w}}(\mathrm{t})\right] /\left[1013.25 \cdot\left(1+0.00367 \cdot \mathrm{T}_{c}(\mathrm{t})\right]\right.
\end{gathered}
$$

$$
\begin{aligned}
& \dot{\mathrm{V}}_{\mathrm{o}} \mathrm{O}_{2}(\mathrm{t})=\dot{\mathrm{V}}_{\mathrm{o}}(\mathrm{t}) \cdot \mathrm{F}_{\mathrm{oC}_{2}} \mathrm{O}_{2}(\mathrm{t}) / 100 \\
& \dot{\mathrm{V}}_{\mathrm{o}} \mathrm{CO}_{2}(\mathrm{t})=\dot{\mathrm{V}}_{\mathrm{o}}(\mathrm{t}) \cdot \mathrm{F}_{\mathrm{oc} \mathrm{CO}_{2}}(\mathrm{t}) / 100 \\
& \dot{\mathrm{V}}_{\mathrm{o}} \mathrm{N}_{2}(\mathrm{t})=\dot{\mathrm{V}}_{\mathrm{o}}(\mathrm{t}) \cdot \mathrm{F}_{\mathrm{o}} \mathrm{N}_{2}(\mathrm{t}) / 100=\dot{\mathrm{V}}_{\mathrm{o}}(\mathrm{t})-\dot{\mathrm{V}}_{\mathrm{O}} \mathrm{O}_{2}(\mathrm{t})-\dot{\mathrm{V}}_{\mathrm{o}} \mathrm{CO}_{2}(\mathrm{t})
\end{aligned}
$$

Next, parameters have to be derived that involve $\dot{V}_{i}(t)$, the flow of the input in STPD. $V_{i}(t)$ may be calculated by using the "haldane" correction. The formula used must incorporate changing $\mathrm{N}_{2}$ fractions and STPD correction of the chamber volume as a function of time

$$
\begin{aligned}
\dot{V}_{i}\left(t_{1+2}\right)=\left[\dot{V}_{0}\left(t_{1+2}\right) \cdot F_{0} N_{2}\left(t_{1+2}\right)+\right. & V_{c}\left(t_{2}\right) \cdot F_{0} N_{2}\left(t_{2}\right) \\
& \left.-V_{c}\left(t_{1}\right) \cdot F_{o} N_{2}\left(t_{1}\right)\right] / F_{i} N_{2}\left(t_{1+2}\right)
\end{aligned}
$$

Now that $\dot{V}_{\mathrm{i}}(\mathrm{t})$ is known, the following parameters are derived

$$
\begin{aligned}
& \dot{\mathrm{V}}_{\mathrm{i}} \mathrm{O}_{2}\left(\mathrm{t}_{1+2}\right)=\dot{\mathrm{V}}_{\mathrm{i}}\left(\mathrm{t}_{1+2}\right) \cdot \mathrm{F}_{\mathrm{i}} \mathrm{O}_{2}\left(\mathrm{t}_{1+2}\right) / 100 \\
& \dot{\mathrm{V}}_{\mathrm{i}} \mathrm{CO}_{2}\left(\mathrm{t}_{1+2}\right)=\dot{\mathrm{V}}_{\mathrm{i}}\left(\mathrm{t}_{1+2}\right) \cdot \mathrm{F}_{\mathrm{i}} \mathrm{CO}_{2}\left(\mathrm{t}_{1+2}\right) / 100 \\
& \dot{\mathrm{V}}_{\mathrm{c}} \mathrm{O}_{2}\left(\mathrm{t}_{1+2}\right)=\left[\mathrm{V}_{\mathrm{c}}\left(\mathrm{t}_{2}\right) \cdot \mathrm{F}_{{ }_{\mathrm{oc}} \mathrm{O}_{2}}\left(\mathrm{t}_{2}\right)-\mathrm{V}_{\mathrm{c}}\left(\mathrm{t}_{1}\right) \cdot \mathrm{F}_{{ }_{\mathrm{oc}} \mathrm{O}_{2}}\left(\mathrm{t}_{1}\right)\right] /\left[100 \cdot\left(\mathrm{t}_{2}-\mathrm{t}_{1}\right)\right] \\
& \dot{\mathrm{V}}_{\mathrm{c}} \mathrm{CO}_{2}\left(\mathrm{t}_{1+2}\right)=\left[\mathrm{V}_{\mathrm{c}}\left(\mathrm{t}_{2}\right) \cdot \mathrm{F}_{\mathrm{oc}} \mathrm{CO}_{2}\left(\mathrm{t}_{2}\right)\right.
\end{aligned}
$$

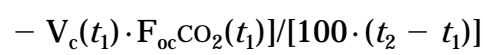

This leaves only $\dot{\mathrm{V}}_{2}$ and $\dot{\mathrm{V}} \mathrm{CO}_{2}$ to be calculated

$$
\begin{gathered}
\dot{\mathrm{V}}_{2}\left(\mathrm{t}_{1+2}\right)=\dot{\mathrm{V}}_{\mathrm{i}} \mathrm{O}_{2}\left(\mathrm{t}_{1+2}\right)-\dot{\mathrm{V}}_{\mathrm{c}} \mathrm{O}_{2}\left(\mathrm{t}_{1+2}\right)-\dot{\mathrm{V}}_{\mathrm{o}} \mathrm{O}_{2}\left(\mathrm{t}_{1+2}\right) \\
\dot{\mathrm{V}} \mathrm{CO}_{2}\left(\mathrm{t}_{1+2}\right)=\dot{\mathrm{V}}_{\mathrm{o}} \mathrm{CO}_{2}\left(\mathrm{t}_{1+2}\right)+\dot{\mathrm{V}}_{\mathrm{c}} \mathrm{CO}_{2}\left(\mathrm{t}_{1+2}\right)-\dot{\mathrm{V}}_{\mathrm{i}} \mathrm{CO}_{2}\left(\mathrm{t}_{1+2}\right)
\end{gathered}
$$

The authors acknowledge Dr. P. Webb for many valuable comments in the field of calorimetry during the past 10 years.

Address for reprint requests: P. F. M. Schoffelen, Dept. of Human Biology, Universiteit Maastricht, PO Box 616, 6200 MD Maastricht, The Netherlands (E-mail: P.Schoffelen@HB.UNIMAAS.NL).

Received 12 March 1997; accepted in final form 23J uly 1997.

\section{REFERENCES}

1. Atwater, W. O., and F. G. Benedict. Experiments on the Metabolism of Matter and Energy in the Human Body. Washington, DC: US Government Printing Office, 1903. (USDA Office of Experiment Stations Bull. No. 136)

2. Benedict, F. G. A helmet for use in clinical studies of gaseous metabolism. N. Engl. J . Med. 203: 150-158, 1930.

3. Brown, D., T. J . Cole, M. J . Dauncey, R. W. Marrs, and P. R. Murgatroyd. Analysis of gaseous exchange in open-circuit indirect calorimetry. Med. Biol. Eng. Comput. 22: 333-338, 1984.

3a. Centre de Recherche Claud-Delorme de L'Air Liquid. Encycl opedie des Gaz. Amsterdam: Elsevier, 1976.

4. Charbonnier, A., C. D. R. J ones, Y. Schutz, P. R. Murgatroyd, R. G. Whitehead, E. J équier, and G. Spinnler. A whole body transportable indirect calorimeter for human use in the tropics. Eur. J. Clin. Nutr. 44: 725-731, 1990.

5. Dauncey, M. J ., P. R. Murgatroyd, and T. J . Cole. A human calorimeter for the direct and indirect measurement of $24 \mathrm{~h}$ energy expenditure. Br. J . Nutr. 39: 557-566, 1978.

6. Henning, B., R. Löfgren, and L. Sjöström. Chamber for indirect calorimetry with improved transient response. Med. Biol. Eng. Comput. 34: 207-212, 1996.

7. Heymsfield, S. B., D. B. Allison, F. X. Pi-Sunyer, and Y. Sun. Columbia respiratory-chamber indirect calorimeter: a new approach to air-flow modelling. Med. Biol. Eng. Comput. 32: 406-410, 1994.

8. J équier, E., and Y. Schutz. Long-term measurements of energy expenditure in humans using a respiration chamber. Am. J . Clin. Nutr. 38: 989-998, 1983. 
9. Kinney, J . M., A. P. Morgan, F. J . Domingues, and K. J . Gildner. A method for the continuous measurement of gas exchange and expired radioactivity in acutely ill patients. Metabolism 13: 205-211, 1964.

10. McLean, J. A., and P. R. Watts. Analytical refinements in animal calorimetry. J . Appl. Physiol. 40: 827-831, 1976.

11. Moon, J . K., C. L. J ensen, and N. F. Butte. Fast-response whole body indirect calorimeter for infants. J . Appl. Physiol. 74: 476-484, 1993.

12. Moon, J . K., F. A. Vohra, O. S. Valerio J imenez, M. R. Puyau, and N. F. B utte. Closed-loop control of carbon dioxide concentration and pressure improves response of room respiration calorimeters. J . Appl. Physiol. 125: 220-228, 1995.

13. Murgatroyd, P. R., H. L. Davies, and A. M. Prentice. Intra-individual variability and measurement noise in estimates of energy expenditure by whole body indirect calorimetry. Br. J . Nutr. 58: 347-356, 1987.

14. Prentice, A. M., G. R. Goldberg, H. L. Davies, P. R. Murgatroyd, and $\mathbf{W}$. Scott. Energy-sparing adaptations in human pregnancy assessed by whole-body calorimetry. Br. J . Nutr. 62 : 5-22, 1989.

15. Ravussin, E., S. Lillioja, T. Anderson, L. Christin, and C. Bogardus. Determinants of 24-hour energy expenditure in man: methods and results using a respiratory chamber. J . Clin. I nvest. 78: 1568-1578, 1986.

16. Rumpler, W. V., J . L. Seale, J . M. Conway, and P. W. Moe. Repeatability of 24-h energy expenditure measurements in humans by indirect calorimetry. Am. J . Clin. Nutr. 51: 147-152, 1990.

17. Seale, J . L., W. V. Rumpler, and P. W. Moe. Description of a direct-indirect room-sized cal orimeter. Am. J . Physiol . 260 (Endocrinol. Metab. 23): E 306-E 320, 1991.

18. Shetty, P. S., M. L. Sheela, P. R. Murgatroyd, and A. V. Kurpad. An open-circuit indirect whole body calorimeter for the continuous measurement of energy expenditure of man in the tropics. Indian J . Med. Res. 85: 453-460, 1987.

19. Treuth, S. M., G. R. Hunter, R. L. Weinsier, and S. H. Kell. Energy expenditure and substrate utilization in older women after strength training: 24-h calorimeter results. J . Appl. Physiol. 78: 2140-2146, 1995.

20. Webb, P., and S. J . Troutman, J r. An instrument for continuous measurement of oxygen consumption. J . Appl. Physiol. 28: 867-871, 1970.

21. Weir, J. B. New methods for calculating metabolic rate with special reference to predicting protein metabolism. J . Physiol. (Lond.) 109: 1-9, 1949.

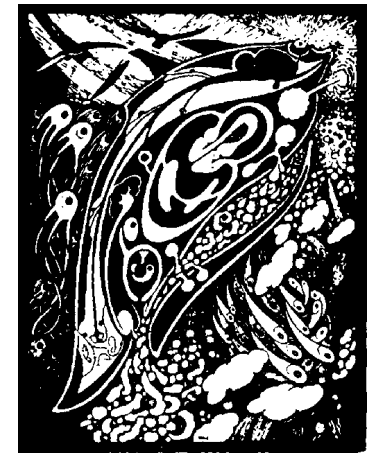

